\title{
Literature Review: Efektivitas, Keamanan, dan Biaya Terapi Imidafenacin untuk Pasien Overactive Bladder
}

\section{Literature Review: Efficacy, Safety, and Cost of Imidafenacin for Patients with Overactive Bladder}

Steven Victoria Halim

Pusat Informasi Obat dan Layanan Kefarmasian (PIOLK), Universitas Surabaya, Indonesia; Fakultas Farmasi, Universitas Surabaya, Indonesia

\section{ARTICLE INFO}

\section{Article history}

Received date

19 Nov 2020

Revised date

23 Nov 2020

Accepted date

26 Nov 2020

\section{Keywords:}

Critical review;

Imidafenacin;

Muscarinic antagonists;

Overactive bladder.

\section{Kata kunci:}

Kajian kritis;

Imidafenacin;

Anti-muskarinik;

Overactive bladder.

\author{
ABSTRACT/ ABSTRAK
}

Imidafenacin is a new antimuscarinic agent in Indonesia that was recently approved in 2019 to treat overactive bladder (OAB) symptoms, including urinary incontinence, urinary frequency, and urinary urgency. As a new $\mathrm{OAB}$ medication in the Indonesian commercial market, a comprehensive review on the efficacy, safety, and cost of imidafenacin are essentially needed to optimize the responsible use of this drug, particularly in the era of universal coverage implementation in Indonesia. This review aimed to describe the profile of imidafenacin and to compare the efficacy, safety, and cost of imidafenacin with the other antimuscarinic drugs in Indonesia, and the guideline recommendations towards when to use imidafenacin for $\mathrm{OAB}$ treatment. Only results from systematic reviews and meta-analyses were used in the efficacy and safety comparison. Our review found that the efficacy of imidafenacin was relatively comparable to the other antimuscarinic drugs in Indonesia, including solifenacin, tolterodine, dan propiverine. Also, a better safety profile was found in the imidafenacin group, in particular, imidafenacin caused less dry mouth and constipation. This could be attributable to the higher affinity of imidafenacin to the M3 receptor resulting in less antimuscarinic effect at the other receptors. From the cost perspective, the cost of medication by using imidafenacin was relatively lower compared to the other antimuscarinic drugs in Indonesia. It, therefore, could be suggested to use imidafenacin as a potential agent for $\mathrm{OAB}$.

\begin{abstract}
Imidafenacin merupakan obat golongan anti muskarinik baru yang memperoleh ijin edar di Indonesia pada tahun 2019 untuk menangani gejala terkait overactive bladder, seperti: inkontinensia dan peningkatan frekuensi berkemih. Sebagai obat baru, kajian terhadap efektivitas, keamanan, dan biaya diperlukan untuk menunjang penggunaan imidafenacin secara bertanggung jawab, terutama di era implementasi jaminan kesehatan nasional $(\mathrm{JKN})$. Kajian naratif ini bertujuan untuk menguraikan profil umum, komparasi efektivitas, keamanan dan biaya imidafenacin dengan anti muskarinik lain yang tersedia di Indonesia, serta rekomendasi penggunaan imidafenacin dalam pedoman terapi. Perbandingan efektivitas dan keamanan imidafenacin hanya didasarkan pada bukti penelitian terpublikasi berupa kajian sistematis dan meta-analisis. Hasil kajian ini menunjukkan efektivitas imidafenacin relatif setara dengan anti muskarinik lain yang tersedia di Indonesia, antara lain: solifenacin, tolterodine, dan propiverine. Selain itu, imidafenacin memiliki profil keamanan yang lebih baik, yakni lebih jarang menyebabkan efek samping berupa mulut kering dan konstipasi. Perbedaan kejadian efek samping tersebut disebabkan tingginya afinitas imidafenacin terhadap reseptor M3, sehingga efek anti muskarinik pada reseptor lainnya relatif rendah. Ditinjau dari segi biaya, biaya terkait obat pada penggunaan imidafenacin lebih murah dibandingkan anti muskarinik yang lain di Indonesia. Atas dasar pertimbangan tersebut, imidafenacin dapat menjadi salah satu obat yang dipertimbangkan untuk digunakan untuk mengobati overactive bladder.
\end{abstract}




\section{PENDAHULUAN}

Overactive Bladder (OAB) merupakan suatu kumpulan gejala (symptoms) yang berkaitan dengan proses berkemih. Adapun gejala yang berkaitan dengan $\mathrm{OAB}$, antara lain: 1) keinginan untuk buang air kecil secara tibatiba dan sulit untuk ditunda (urinary urgency) dengan atau tanpa disertai dengan keluarnya urin secara tiba-tiba dan tidak terkendali (incontinence), 2) peningkatan frekuensi buang air kecil, dan 3) berkemih pada malam hari (nocturia) (Arnold, et al., 2012; Corcos, et al., 2017; Wolff, et al., 2014). Sebuah data studi epidemiologi pada beberapa negara menunjukkan bahwa prevalensi OAB bervariasi antara 11,8 $35,6 \%$ tanpa terdapat perbedaan tingkat kejadian pada pria maupun wanita yang bermakna (Eapen \& Radomski, 2016). Kejadian OAB meningkat seiring dengan pertambahan usia dan dapat disebabkan, salah satunya, oleh penurunan fungsi fisiologi sistem urinasi pada pasien lanjut usia (Eapen \& Radomski, 2016; Wolff, et al., 2014). Selain hal tersebut, terdapat beberapa hal yang dapat menyebabkan $\mathrm{OAB}$, antara lain: kelemahan otot pada bagian pelvic, gangguan saraf, infeksi, dan penggunaan obat (Shah \& Badlani, 2002). Terjadinya $\mathrm{OAB}$ dapat menyebabkan penderita merasa terganggu ataupun malu sehingga berpotensi menurunkan kualitas hidup dan bahkan produktivitas kerja.

Terapi OAB yang direkomendasikan oleh sebagian besar pedoman terapi dapat diklasifilasikan menjadi dua (2) lini terapi. Terapi lini pertama pada pasien $\mathrm{OAB}$ meliputi: terapi perilaku (behavioural therapy), perubahan pola hidup, dan pemberian edukasi kepada pasien. Beberapa bentuk terapi perilaku yang direkomendasikan antara lain: bladder training (seperti: latihan untuk menunda berkemih, pengaturan jadwal untuk berkemih, dan lainnya) dan pelvic floor muscle therapy (PMFT). Pasien dengan $\mathrm{OAB}$ juga disarankan untuk mengubah pola hidup dengan menghindari minuman yang mengandung kafein (teh dan kopi) dan alkohol, berhenti merokok, dan menurunkan berat badan bagi pasien obesitas. Selain itu, penderita juga disarankan untuk melakukan olahraga secara teratur dengan mempertimbangkan terdapat bukti penelitian yang menunjukkan efektivitas olahraga dalam memperkuat otot pelvic floor yang berdampak pada mengurangi gejala OAB. Bila terapi lini pertama ini tidak berhasil, terapi lini kedua dapat diberikan, yakni meliputi penggunaan obat golongan $\beta 3$-adrenoreseptor dan antimuskarinik. Penggunaan kedua golongan obat tersebut terbukti efektif untuk mengatasi gejala OAB (Arnold, et al., 2012; Corcos, et al., 2017; Gormley, et al., 2012; Shah \& Badlani, 2002).

Imidafenacin merupakan salah satu obat golongan anti muskarinik terbaru yang memperoleh ijin edar oleh Badan Pengawas Obat dan Makanan Republik Indonesia (BPOM RI) pada tahun 2019 (Badan Pengawas Obat dan Makanan RI, 2019). Hingga saat ini, terdapat empat (4) obat golongan antimuskarinik yang digunakan pada OAB dan tersedia di Indonesia, yaitu: solifenacin, tolterodine, propiverine, dan imidafenacin. Sebagai obat golongan antimuskarinik terbaru, imidafenacin memiliki beberapa profil farmakokinetika dan farmakodinamika yang berbeda dengan obat golongan antimuskarinik terdahulu (Maggiore, et al., 2013; Takeuchi, et al., 2013; Wu, et al., 2020; Yamada, et al., 2018). Sebagai contoh, peningkatan selektivitas imidafenacin terhadap salah satu reseptor yang berperan penting pada proses terjadinya OAB, yakni reseptor muskarinik 3 (M3). Namun demikian, hal tersebut belum dapat mengindikasikan bahwa penggunaan imidafenacin lebih efektif dalam mengatasi kumpulan gejala $\mathrm{OAB}$ serta memiliki profil keamanan yang lebih baik dibandingkan dengan empat obat yag telah ada di Indonesia sebelumnya. Selain efektivitas dan keamanan, peningkatan aktivitas secara farmakodinamika belum tentu dapat dikatakan cost-effective jika dibandingkan dengan jenis terapi yang lain. Kajian yang secara utuh membandingkan efektivitas, keamanan, dan biaya penggunaan imidafenacin dengan terapi golongan antimuskarinik lain yang tersedia di Indonesia dibutuhkan agar ketepatan penggunaan imidafenacin dapat dioptimalkan. Ketepatan penggunaan obat, terlepas dari jenis obat yang digunakan, perlu diupayakan seoptimal mungkin di era implementasi sistem Jaminan Kesehatan Nasional (JKN) untuk menekankan pembiayaan kesehatan yang tidak diperlukan, termasuk pengobatan dengan obat yang lebih mahal dari seharusnya.

Tujuan dari kajian naratif ini adalah menggambarkan informasi umum imidafenacin, perbandingan efektivitas dan keamanan obat, posisi imidafenacin sebagai pilihan terapi dalam panduan terapi (clinical guidelines), serta perbandingan biaya imidafenacin dengan golongan antimuskarinik yang lainnya. Informasi umum imidafenacin yang dimaksud pada kajian ini meliputi: mekanisme kerja, indikasi, serta profil farmakokinetika dan farmakodinamika obat. Data yang digunakan untuk membandingkan efektivitas dan keamanan imidafenacin 
dengan obat golongan antimuskarinik lain diperoleh dari artikel terpublikasi yang berbentuk kajian sistematis dan meta analisis. Dasar pemilihan kedua jenis pustaka tersebut dalam kajian naratif ini adalah level of evidence keduanya yang menduduki posisi tertinggi dalam tingkatan bukti penelitian. Beberapa parameter terkait efektivitas yang diamati pada kajian pustaka ini meliputi: kejadian urgency incontinence, micturitions, perubahan nilai overactive bladder symptom score, dan volume urin setiap micturitions. Sedangkan terkait keamanan, beberapa kejadian efek samping dalam setiap meta analisis dipaparkan secara mendetil pada kajian pustaka ini.

\section{PEMBAHASAN}

\section{Mekanisme Kerja dan Indikasi}

Asetilkolin merupakan salah satu neurotransmiter yang berperan sangat penting terhadap terjadinya $\mathrm{OAB}$ karena asetilkolin memiliki efek terhadap kontraksi otot polos. Salah satu reseptor tempat asetilkolin berikatan adalah reseptor muskarinik. Secara umum, terdapat lima (5) subtipe reseptor muskarinik, yaitu: M1-M5 yang tersebar diberbagai bagian tubuh. Pada otot polos kandung kemih (destrusor), terdapat bayak reseptor M2 dan M3. Stimulasi terhadap kedua reseptor tersebut menyebabkan kontraksi otot destrusor dan, lebih lanjut, memicu terjadinya proses urinasi (Jayarajan \& Radomski, 2013; Maggiore, et al., 2013; Yamada, et al., 2018). Selain dikaitkan dengan aktivitas antagonisnya terhadap reseptor M3 (postjunctional), imidafenacin juga berikatan dengan reseptor M1 (prejunctional) untuk dapat menghasilkan pengendalian gejala OAB. Aktivitas antagonis imidafenacin pada M1 dapat menyebabkan terjadinya hambatan pelepasan asetilkolin dari saraf terminal di kandung kemih. Sebagaimana dinyatakan dalam penelitian Kobayashi, et al. (2007), afinitias imidafenacin terhadap M1 dan M3 relatif lebih besar dibandingkan terhadap reseptor muskarinik yang lain (Kobayashi, et al., 2011).

Selektivitas terhadap reseptor M1 dan M3 (pada destrusor) inilah yang menjadi salah satu tanda spesifik yang membedakan imidafenacin dengan golongan antimuskarinik yang lain di Indonesia, seperti: solifenacin (hanya memiliki afinitas yang baik terhadap M3), tolterodine dan propiverin (memiliki afinitas terhadap M1, M2, M3, M4, M5). Selain itu, selektivitas imidafenacin terhadap reseptor M3 di detrusor lebih tinggi dibandingkan dengan reseptor M3 di bagian tubuh lainnya, termasuk di usus dan kelenjar saliva. Hal tersebut menyebabkan profil ROTD imidafenacin yang berkaitan dengan organ lain, seperti: mulut kering dan konstipasi relatif lebih jarang terjadi bila dibandingkan dengan golongan antimuskarinik lainnya (Jayarajan \& Radomski, 2013; Maggiore, et al., 2013).

Imidafenacin pertama kali memperoleh ijin edar di Jepang pada tahun 2010 dengan nama Staybla ${ }^{\circledR}$ dan Uritos ${ }^{\circledR}$. Sembilan tahun kemudian (2019), imidafenacin masuk ke Indonesia dan memperoleh ijin edar oleh BPOM dengan nama dagang Uritos ${ }^{\circledR}$. Indikasi imidafenacin yang disetujui di Indonesia dama dengan ijin edar di negara asalnya, yaitu: terapi $\mathrm{OAB}$, urinary incontinency, peningkatan frekuensi berkemih, dan urinary urgency. Bentuk sediaan Uritos ${ }^{\circledR}$ adalah tablet salut dengan kandungan imidafenacin sebesar $0,1 \mathrm{mg} /$ tablet. Dosis yang direkomendasikan adalah 2 kali 1 tablet sehari setelah makan pagi dan sore (Badan Pengawas Obat dan Makanan Republik Indonesia, 2015c; Ono Pharmaceutical Co, 2010).

\section{Profil Farmakokinetika dan Farmakodinamika}

$\begin{array}{ll}\text { Tabel 1. Farmakokinetika } & \begin{array}{r}\text { dan } \\ \text { Farmakodinamika } \\ \text { (Takeuchi et al., 2013) }\end{array}\end{array}$

\begin{tabular}{|c|c|}
\hline $\begin{array}{l}\text { Parameter } \\
\text { Farmakokinetika }\end{array}$ & Keterangan \\
\hline Bioavailabilitas & $57,8 \%$ \\
\hline Onset of action & $1-3 \mathrm{jam}$ \\
\hline Volume distribusi & $43,9 \mathrm{~L}$ \\
\hline Ikatan obat protein & $\begin{array}{l}\text { 88\% (albumin dan } \alpha 1 \\
\text { asam glikoprotein }\end{array}$ \\
\hline Waktu paruh & $\begin{array}{l}2,9 \text { jam } \\
\text { Via enzim CYP3A4 dan }\end{array}$ \\
\hline Metabolisme & $\begin{array}{l}\text { UGT1A2 menjadi } \\
\text { metabolit inaktif }\end{array}$ \\
\hline $\begin{array}{l}\text { Eliminasi } \\
\text { Farmakodinamika }\end{array}$ & Urin $(65,6 \%)$ \\
\hline $\begin{array}{l}\text { Afinitas terhadap } \\
\text { reseptor muskarinik }\end{array}$ & $\mathrm{M} 3 \geq \mathrm{M} 1>\mathrm{M} 2$ \\
\hline
\end{tabular}

Bioavalabilitas imidafenacin setelah pemberian oral adalah $57,8 \%$ dan mula kerja obat (onset of action) dicapai setelah 1-3 jam pemberian. Pada saat obat dalam sirkulasi sistemik, sebanyak lebih kurang $88 \%$ obat terikat pada protein dalam plasma, yaitu: albumin dan $\alpha 1$-asam glikoprotein. Hasil metabolisme imidafenacin adalah metabolit tidak aktif (Takeuchi, et al., 2013). 


\section{Efektivitas dan Keamanan Imidafenacin}

\section{Tabel 2. Perbandingan Efektivitas Imidafenacin dengan Golongan Antimuskarinik Lain} (Huang, et al., 2015; Wu, et al., 2020)

\begin{tabular}{|c|c|c|c|}
\hline Pengarang/ Populasi & Terapi & $\begin{array}{c}\text { Jumlah } \\
\text { penelitian }\end{array}$ & Outcome penelitian \\
\hline \multirow{18}{*}{ Wu et al. (2020)/ } & $\begin{array}{l}\text { Imidafenacin } v s \\
\text { antimuskarinik lain } \\
\text { (tolterodine) }\end{array}$ & 1 & $\begin{array}{l}\text { Episode urgency dalam sehari selama } 2 \text { minggu: tolterodine menunjukkan } \\
\text { pengurangan episode } u r g e n c y \text { lebih besar secara signifikan dibandingkan } \\
\text { imidafenacin (MD } 0,90 ; 95 \% \text { CI } 0,17-1,63 \text { ) }\end{array}$ \\
\hline & \multirow{3}{*}{$\begin{array}{l}\text { Imidafenacin } v s \\
\text { antimuskarinik lain } \\
\text { (tolterodine, } \\
\text { fesoterodine, } \\
\text { propiverine) }\end{array}$} & 3 & $\begin{array}{l}\text { Episode urgency dalam sehari selama } 4 \text { minggu: tidak berbeda signifikan } \\
\text { pada pengurangan episode } u \text { rgency pada kedua kelompok (MD } 0,31 ; 95 \% \mathrm{CI} \\
-0,22-0,83 \text { ) }\end{array}$ \\
\hline & & 3 & $\begin{array}{l}\text { Episode urgency dalam sehari selama } 8 \text { minggu: tidak berbeda signifikan } \\
\text { pada pengurangan episode } \text { urgency pada kedua kelompok (MD - } 0,10 ; 95 \% \mathrm{CI} \\
-0,63-0,43 \text { ) }\end{array}$ \\
\hline & & 4 & $\begin{array}{l}\text { Episode urgency dalam sehari selama } 12 \text { minggu: tidak berbeda signifikan } \\
\text { pada pengurangan episode } \text { urgency pada kedua kelompok (MD } 0,21 ; 95 \% \mathrm{CI} \\
-0,14-0,56 \text { ) }\end{array}$ \\
\hline & $\begin{array}{l}\text { Imidafenacin } v s \\
\text { antimuskarinik lain } \\
\text { (tolterodine) }\end{array}$ & 1 & $\begin{array}{l}\text { Kejadian urgency incontinence dalam sehari selama } 2 \text { minggu: tidak berbeda } \\
\text { signifikan pada kejadian urgency incontinence antara } 2 \text { kelompok (MD -0,20; } \\
95 \% \text { CI }-0,66-0,26)\end{array}$ \\
\hline & \multirow{3}{*}{$\begin{array}{l}\text { Imidafenacin } v s \\
\text { antimuskarinik lain } \\
\text { (tolterodine, } \\
\text { fesoterodine, } \\
\text { propiverine) }\end{array}$} & 3 & $\begin{array}{l}\text { Kejadian urgency incontinence dalam sehari selama } 4 \text { minggu: tidak berbeda } \\
\text { signifikan pada kejadian urgency incontinence antara } 2 \text { kelompok (MD -0,03; } \\
95 \% \text { CI -0,37-0,32) }\end{array}$ \\
\hline & & 3 & $\begin{array}{l}\text { Kejadian urgency incontinence dalam sehari selama } 8 \text { minggu: tidak berbeda } \\
\text { signifikan pada kejadian urgency incontinence antara } 2 \text { kelompok (MD }-0,17 \text {; } \\
95 \% \text { CI }-0,51-0,18 \text { ) }\end{array}$ \\
\hline & & 4 & $\begin{array}{l}\text { Kejadian urgency incontinence dalam sehari selama } 12 \text { minggu: tidak } \\
\text { berbeda signifikan pada kejadian urgency incontinence antara } 2 \text { kelompok } \\
(\mathrm{MD}-0,01 ; 95 \% \mathrm{CI}-0,23-0,20)\end{array}$ \\
\hline & $\begin{array}{l}\text { Imidafenacin } v s \\
\text { antimuskarinik lain } \\
\text { (tolterodine) }\end{array}$ & 1 & $\begin{array}{l}\text { Micturitions dalam sehari selama } 2 \text { minggu: tidak berbeda signifikan pada } \\
\text { kejadian micturitions antara } 2 \text { kelompok (MD - } 0,30 ; 95 \% \mathrm{CI}-0,96-0,36)\end{array}$ \\
\hline & \multirow{3}{*}{$\begin{array}{l}\text { Imidafenacin } v s \\
\text { antimuskarinik lain } \\
\text { (tolterodine, } \\
\text { fesoterodine, } \\
\text { propiverine) }\end{array}$} & 4 & $\begin{array}{l}\text { Micturitions dalam sehari selama } 4 \text { minggu: tidak berbeda signifikan pada } \\
\text { kejadian micturitions antara } 2 \text { kelompok (MD } 0,12 ; 95 \% \text { CI }-0,10-0,34)\end{array}$ \\
\hline & & 4 & $\begin{array}{l}\text { Micturitions dalam sehari selama } 8 \text { minggu: tidak berbeda signifikan pada } \\
\text { kejadian micturitions antara } 2 \text { kelompok (MD } 0,23 ; 95 \% \text { CI } 0,00-0,47)\end{array}$ \\
\hline & & 4 & $\begin{array}{l}\text { Micturitions dalam sehari selama } 12 \text { minggu: tidak berbeda signifikan pada } \\
\text { kejadian micturitions antara } 2 \text { kelompok (MD } 0,18 ; 95 \% \text { CI }-0,07-0,42 \text { ) }\end{array}$ \\
\hline & $\begin{array}{l}\text { Imidafenacin } v s \\
\text { antimuskarinik lain } \\
\text { (tolterodine) }\end{array}$ & 1 & $\begin{array}{l}\text { Perubahan nilai OABSS dalam } 2 \text { minggu: tidak berbeda signifikan pada } \\
\text { perubahan nilai OABSS pada kedua kelompok (MD } 0,20 ; 95 \% \text { CI }-1,46-1,86 \text { ) }\end{array}$ \\
\hline & $\begin{array}{l}\text { Imidafenacin } v s \\
\text { antimuskarinik lain } \\
\text { (tolterodine, } \\
\text { solifenacin) }\end{array}$ & 4 & $\begin{array}{l}\text { Perubahan nilai OABSS dalam } 4 \text { minggu: tidak berbeda signifikan pada } \\
\text { perubahan nilai OABSS pada kedua kelompok (MD } 0,39 ; 95 \% \text { CI }-0,35-1,12 \text { ) }\end{array}$ \\
\hline & $\begin{array}{l}\text { Imidafenacin } v s \\
\text { antimuskarinik lain } \\
\text { (tolterodine) }\end{array}$ & 1 & $\begin{array}{l}\text { Perubahan nilai OABSS dalam } 8 \text { minggu: tidak berbeda signifikan pada } \\
\text { perubahan nilai OABSS pada kedua kelompok (MD } 0,80 ; 95 \% \text { CI }-0,89-2,49 \text { ) }\end{array}$ \\
\hline & $\begin{array}{l}\text { Imidafenacin } v s \\
\text { antimuskarinik lain } \\
\text { (tolterodine, } \\
\text { solifenacin) }\end{array}$ & 4 & $\begin{array}{l}\text { Perubahan nilai OABSS dalam } 12 \text { minggu: tidak berbeda signifikan pada } \\
\text { perubahan nilai OABSS pada kedua kelompok (MD } 0,48 ; 95 \% \text { CI }-0,27-1,24 \text { ) }\end{array}$ \\
\hline & $\begin{array}{l}\text { Imidafenacin } v s \\
\text { antimuskarinik lain } \\
\text { (solifenacin) }\end{array}$ & 1 & $\begin{array}{l}\text { Perubahan nilai OABSS dalam } 24 \text { minggu: tidak berbeda signifikan pada } \\
\text { perubahan nilai OABSS pada kedua kelompok (MD } 0,86 ; 95 \% \text { CI }-0,23-1,95 \text { ) }\end{array}$ \\
\hline & $\begin{array}{l}\text { Imidafenacin } v s \\
\text { antimuskarinik lain } \\
\text { (solifenacin) }\end{array}$ & 1 & $\begin{array}{l}\text { Perubahan nilai OABSS dalam } 52 \text { minggu: tidak berbeda signifikan pada } \\
\text { perubahan nilai OABSS pada kedua kelompok (MD - } 0,28 ; 95 \% \mathrm{CI}-1,24- \\
0,68 \text { ) }\end{array}$ \\
\hline Huang et al (2015)/ & \multirow{4}{*}{$\begin{array}{l}\text { Imidafenacin } v s \\
\text { propiverine }\end{array}$} & 4 & $\begin{array}{l}\text { Episode urgency incontinence dalam } 1 \text { minggu: tidak berbeda signifikan } \\
\text { antara kedua kelompok (MD } 1,23 ; 95 \% \text { CI }-0,19-2,65)\end{array}$ \\
\hline \multirow{3}{*}{$\begin{array}{l}\text { Pasien berusia } \geq 19 \text { tahun, } \\
\text { mengalami micturition }(\geq \\
8 \text { BAK per hari), urgency } \\
\text { ( } \geq 1 \text { episode per hari) dan } \\
\text { urine incontinence }(\geq 5 \\
\text { episode per minggu) }\end{array}$} & & 4 & $\begin{array}{l}\text { Episode } \text { urgency dalam sehari: tidak berbeda signifikan antara kedua } \\
\text { kelompok (MD } 0,26 ; 95 \% \text { CI }-0,11-0,63 \text { ) }\end{array}$ \\
\hline & & 4 & $\begin{array}{l}\text { Rata-rata micturitions per hari: tidak berbeda signifikan antara kedua } \\
\text { kelompok (MD } 0,01 ; 95 \% \text { CI }-0,30-0,31 \text { ) }\end{array}$ \\
\hline & & 4 & $\begin{array}{l}\text { Volume urin setiap micturitions: pasien yang memperoleh terapi imidafenacin } \\
\text { memiliki volume urin pada setiap kejadian micturitions lebih sedikit secara } \\
\text { signifikan dibandingkan kelompok propiverine (MD -13,04; } 95 \% \text { CI -20,45, - } \\
5,62 \text { ) }\end{array}$ \\
\hline \multicolumn{4}{|l|}{ Huang et al (2015)/ } \\
\hline $\begin{array}{l}\text { Pasien berusia } \geq 20 \text { tahun, } \\
\text { mengalami } \text { urgency }(\geq 1 \\
\text { episode per hari), nilai } \\
\text { OABSS } \geq 3 \text { poin }\end{array}$ & $\begin{array}{l}\text { Imidafenacin } v s \\
\text { solifenacin }\end{array}$ & 6 & $\begin{array}{l}\text { Skor OABSS: tidak berbeda signifikan perubahan skor OABSS pada kedua } \\
\text { kelompok (MD } 0,48 ; 95 \% \text { CI }-0,08-1,03 \text { ) }\end{array}$ \\
\hline
\end{tabular}

Keterangan: BAK: buang air kecil, CI: confidence intervals, MD: mean difference, micturitions: berkemih/urinasi, OAB: overactive bladder, OABSS: overactive bladder symptom score (0-15 poin), vs: versus 
Tabel 3. Perbandingan Keamanan Imidafenacin dengan Golongan Antimuskarinik Lain (Huang et al., 2015; Wu et al., 2020)

\begin{tabular}{|c|c|c|c|}
\hline Pengarang/ Populasi & Terapi & $\begin{array}{c}\text { Jumlah } \\
\text { penelitian }\end{array}$ & Outcome penelitian \\
\hline \multirow{10}{*}{ Wu et al. (2020)/ } & \multirow{2}{*}{$\begin{array}{l}\text { Imidafenacin } v s \\
\text { antimuskarinik } \\
\text { lain } \\
\text { (tolterodine, } \\
\text { fesoterodine, } \\
\text { solifenacin, } \\
\text { propiverine) }\end{array}$} & 6 & $\begin{array}{l}\text { Kejadian efek samping mulut kering: efek } \\
\text { samping mulut kering lebih sering terjadi } \\
\text { secara signifikan pada kelompok antimuskarinik } \\
\text { lain selain imidafenacin (RR } 0,87 ; 95 \% \text { CI } 0,75 \text { - } \\
1,00)\end{array}$ \\
\hline & & 6 & $\begin{array}{l}\text { Kejadian efek samping konstipasi: efek samping } \\
\text { konstipasi lebih sering terjadi secara signifikan } \\
\text { pada kelompok antimuskarinik lain selain } \\
\text { imidafenacin (RR } 0,68 ; 95 \% \text { CI } 0,50-0,93)\end{array}$ \\
\hline & $\begin{array}{l}\text { Imidafenacin } v s \\
\text { antimuskarinik } \\
\text { lain } \\
\text { (fesoterodine, } \\
\text { solifenacin, } \\
\text { propiverine) }\end{array}$ & 5 & $\begin{array}{l}\text { Kejadian efek samping pandangan kabur: tidak } \\
\text { berbeda signifikan antara kedua kelompok (RR } \\
0,43 ; 95 \% \text { CI } 0,38-1,08)\end{array}$ \\
\hline & \multirow{4}{*}{$\begin{array}{l}\text { Imidafenacin } v s \\
\text { antimuskarinik } \\
\text { lain } \\
\text { (propiverine) }\end{array}$} & 2 & $\begin{array}{l}\text { Temuan sel darah putih di urin: tidak berbeda } \\
\text { signifikan antara kedua kelompok (RR } 0,80 ; \\
95 \% \text { CI } 0,60-1,32 \text { ) }\end{array}$ \\
\hline & & 2 & $\begin{array}{l}\text { Kejadian sakit kepala: tidak berbeda signifikan } \\
\text { antara kedua kelompok (RR } 1,05 ; 95 \% \text { CI } 0,48 \text { - } \\
2,39 \text { ) }\end{array}$ \\
\hline & & 2 & $\begin{array}{l}\text { Rasa tidak nyaman pada perut: tidak berbeda } \\
\text { signifikan antara kedua kelompok (RR } 0,72 ; \\
95 \% \text { CI } 0,52-1,67)\end{array}$ \\
\hline & & 2 & $\begin{array}{l}\text { Mual: tidak berbeda signifikan antara kedua } \\
\text { kelompok (RR } 0,78 ; 95 \% \text { CI } 0,29-2,05)\end{array}$ \\
\hline & $\begin{array}{l}\text { Imidafenacin } v s \\
\text { antimuskarinik } \\
\text { lain } \\
\text { (tolterodine, } \\
\text { fesoterodine, } \\
\text { propiverine) }\end{array}$ & 3 & $\begin{array}{l}\text { Kejadian mata kering: tidak berbeda signifikan } \\
\text { antara kedua kelompok (RR } 0,42 ; 95 \% \text { CI } 0,14- \\
1,27)\end{array}$ \\
\hline & $\begin{array}{l}\text { Imidafenacin } v s \\
\text { antimuskarinik } \\
\text { lain } \\
\text { (tolterodine, } \\
\text { propiverine) }\end{array}$ & 2 & $\begin{array}{l}\text { Kejadian nyeri perut: tidak berbeda signifikan } \\
\text { antara kedua kelompok (RR 0,29; } 95 \% \text { CI 0,07- } \\
1,18)\end{array}$ \\
\hline & $\begin{array}{l}\text { Imidafenacin } v s \\
\text { antimuskarinik } \\
\text { lain } \\
\text { (tolterodine, } \\
\text { solifenacin, } \\
\text { propiverine) }\end{array}$ & 5 & $\begin{array}{l}\text { Tingkat drop out akibat efek samping: jumlah } \\
\text { partisipan drop out dari penelitian akibat efek } \\
\text { samping lebih rendah secara signifikan terjadi } \\
\text { pada kelompok imidafenacin (RR } 0,51 ; 95 \% \text { CI } \\
0,29-0,89)\end{array}$ \\
\hline \multirow{2}{*}{$\begin{array}{l}\text { Pasien berusia } \geq 19 \\
\text { tahun, mengalami } \\
\text { micturition ( } \geq 8 \text { BAK } \\
\text { per hari), urgency }(\geq 1 \\
\text { episode per hari) dan } \\
\text { urine incontinence ( } \geq 5 \\
\text { episode per minggu) }\end{array}$} & \multirow{2}{*}{$\begin{array}{l}\text { Imidafenacin } v s \\
\text { propiverine }\end{array}$} & 2 & $\begin{array}{l}\text { Kejadian efek samping mulut kering: efek } \\
\text { samping mulut kering lebih sering terjadi } \\
\text { secara signifikan pada kelompok propiverine } \\
(\text { OR } 0,73 ; 95 \% \text { CI } 0,54-0,98)\end{array}$ \\
\hline & & 2 & $\begin{array}{l}\text { Kejadian efek samping umum: efek samping } \\
\text { umum lebih sering terjadi secara signifikan } \\
\text { pada kelompok propiverine (OR } 0,63 ; 95 \% \text { CI } \\
0,46-0,88)\end{array}$ \\
\hline \multirow{2}{*}{$\begin{array}{l}\text { Huang et al }(2015) / \\
\text { Pasien berusia } \geq 20 \\
\text { tahun, mengalami } \\
\text { urgency }(\geq 1 \text { episode } \\
\text { per hari), nilai OABSS } \\
\geq 3 \text { poin }\end{array}$} & \multirow{2}{*}{$\begin{array}{l}\text { Imidafenacin } v s \\
\text { solifenacin }\end{array}$} & 2 & $\begin{array}{l}\text { Kejadian efek samping konstipasi: efek samping } \\
\text { konstipasi lebih sering terjadi secara signifikan } \\
\text { pada kelompok solifenacin (OR } 0,21 ; 95 \% \text { CI } \\
0,08-0,53)\end{array}$ \\
\hline & & 2 & $\begin{array}{l}\text { Kejadian efek samping umum: efek samping } \\
\text { umum lebih sering terjadi secara signifikan } \\
\text { pada kelompok solifenacin (OR } 0,33 ; 95 \% \text { CI } \\
0,15-0,71)\end{array}$ \\
\hline
\end{tabular}


Hasil kajian sistematik dan meta-analisis terkait perbedaan efektivitas imida-fenacin dengan golongan antimuskarinik lain pada tabel 2, dan kajian terkait keamanan pada tabel 3 terlihat mayoritas penelitian menunjukkan efektivitas imidafenacin yang setara dibandingkan dengan antimuskarinik yang lain. Dengan kata lain, penggunaan imidafenacin tidak menghasilkan efek positif terhadap pasien yang lebih superior dibandingkan dengan pembanding termasuk tolterodine, fesoterodine, propiverine, dan solifenacin. Ditinjau dari sisi keamanan penggunaan, imidafenacin lebih jarang menyebabkan ROTD berupa mulut kering (relative risk $[\mathrm{RR}] 0,87 ; 95 \%$ confidence interval [CI] 0,75-1,00) dan konstipasi (RR 0,68; 95\% CI 0,50-0,93) bila dibandingkan dengan golongan anti-muskarinik lainnya (Huang, et al., 2015; Nazir, et al., 2018; Wu, et al., 2020). Namun demikian, kejadian jenis ROTD yang lain relatif tidak berbeda secara signifikan antara kelompok yang mendapat imidafenacin dan antimiskarinik lain yang ada di Indonesia.

\section{Posisi Imidafenacin sebagai Pilihan Terapi}

Pada pedoman terapi yang direkomendasikan oleh Canadian Urological Association (CUA) tahun 2017, dinyatakan bahwa penggunaan obat antimuskarinik merupakan terapi lini kedua terapi $\mathrm{OAB}$ pada pasien dewasa. Obat antimuskarinik dapat mulai diberikan setelah pasien belum memberikan respon yang baik terhadap terapi OAB lini pertama, yaitu: terapi perilaku (seperti: latihan berkemih dengan jadwal tertentu). Pilihan jenis obat golongan antimuskarinik yang dapat dipilih berdasarkan panduan terapi tersebut, antara lain: oksibutin, tolterodine, darifenacin, trospium, solifenacin, propiverine, dan fesoterodine. Tiga jenis antimuskarinik yang direkomendasikan oleh pedoman terapi CUA (tolterodine, solifenacin, dan propiverine) tersedia di Indonesia. Imidafenacin belum menjadi pilihan obat pada panduan terapi tersebut (Corcos, et al., 2017).

Penempatan obat golongan antimuskarinik sebagai lini kedua terapi $\mathrm{OAB}$ juga direkomendasikan oleh pedoman terapi American Urological Association (AUA) tahun 2017. Selain antimuskarinik, panduan terapi AUA juga merekomendasikan obat golongan $\beta 3$ adrenoreseptor, seperti: mirabegron. Sama halnya dengan panduan terapi CUA, imidafenacin juga belum direkomendasikan oleh panduan terapi AUA (Gormley, et al., 2012).

Penting untuk disampaikan bahwa tidak tercantumnya imidafenacin pada kedua pedoman terapi tersebut tidak berarti bahwa imidafenacin perlu dihindari penggunaannya pada semua kasus OAB. Keputusan untuk menggunakan imidafenacin dapat dilakukan ketika penilaian klinis dari dokter memastikan bahwa pasien akan mendapat keutungan dengan imidafenacin dibandingkan dengan jenis obat yang lain. Selain itu, pada kasus dimana pasien memiliki riwayat ROTD akibat penggunaan jenis obat yang lain, imidafenacin dapat dipertimbangkan pemberiannya. Selain efektivitas dan keamanan seperti telah dipaparkan pada bagian sebelumnya, harga penggunaan imidafenacin perlu dipertimbangkan sebelum memutuskan untuk menggunakan imidafenacin sebagai terapi.

\section{Perbandingan Biaya Imidafenacin dengan Obat Antimuskarinik Lain}

Biaya medis langsung (direct medical cost) terkait penggunaan obat imidafenacin per-hari, dengan mempertimbangkan harga di Indonesia, relatif lebih kecil bila dibandingkan dengan obat golongan antimuskarinik lainnya, seperti: solifenacin $(10 \mathrm{mg})$, tolterodine, dan propiverine. Bila ditinjau dari biaya untuk satu (1) siklus pengobatan, yaitu: maksimal 12 minggu, biaya medis langsung dari penggunaan imidafenacin juga relatif lebih sedikit dibandingkan dengan jenis antimuskarinik yang lain (Badan Pengawas Obat dan Makanan Republik Indonesia, 2015a; 2015b; 2015c; 2015d). Detil perbandingan harga antar jenis obat golongan antimuskarinik yang tersedia di Indonesia dapat dilihat pada tabel 4. 
Tabel 4. Perbandingan Harga Obat Golongan Antimuskarinik (Badan Pengawas Obat dan Makanan Republik Indonesia, 2015a; 2015b; 2015c; 2015d)

\begin{tabular}{|c|c|c|c|c|}
\hline Obat & $\begin{array}{l}\text { Merk, kekuatan } \\
\text { dan harga }\end{array}$ & Dosis & Biaya & Biaya per siklus \\
\hline Imidafenacin & $\begin{array}{l}\text { Uritos }^{\circledR} 0,1 \mathrm{mg} \\
\text { dengan harga } \\
\text { Rp. } 6.405\end{array}$ & $\begin{array}{l}2 \text { kali sehari } \\
0,1 \mathrm{mg}\end{array}$ & $\begin{array}{l}\text { Biaya per-hari: } \\
2 \times \text { Rp. } 6.405= \\
\text { Rp. } 12.810\end{array}$ & $\begin{array}{l}\text { Biaya per-siklus:* } \\
\text { Rp. } 1.076 .040\end{array}$ \\
\hline Solifenacin & $\begin{array}{l}\text { Vesicare }^{\circledR} 10 \mathrm{mg} \\
\text { dengan harga } \\
\text { Rp. } 22.750\end{array}$ & $5-10 \mathrm{mg}$ per hari & $\begin{array}{l}\text { Biaya per-hari: } \\
\text { Kekuatan 5mg: } \\
\text { Rp. } 11.375 \\
\text { Kekuatan 10mg: } \\
\text { Rp. } 22.750\end{array}$ & $\begin{array}{l}\text { Biaya per-siklus:* } \\
\text { Kekuatan 5mg: } \\
\text { Rp. } 955.500 \\
\text { Kekuatan 10mg: } \\
\text { Rp. } 1.911 .000\end{array}$ \\
\hline Tolterodine & $\begin{array}{l}\text { Destrusitol }^{\circledR} 2 \mathrm{mg} \\
\text { dengan harga } \\
\text { Rp. } 11.800 \\
\text { Mictonorm } \\
{ }^{\circledR} 15 \\
\text { mg dengan harga } \\
\text { Rp. } 12.345\end{array}$ & $\begin{array}{l}2 \text { kali sehari } \\
15 \mathrm{mg}\end{array}$ & $\begin{array}{l}\text { Biaya per-hari: } \\
2 \times \text { Rp. } 11.800= \\
\text { Rp. } 23.600 \\
\text { Biaya per-hari: } \\
2 \times \text { Rp. } 12.345= \\
\text { Rp. } 24.690\end{array}$ & $\begin{array}{l}\text { Biaya per-siklus:* } \\
\text { Rp. } 1.982 .000\end{array}$ \\
\hline
\end{tabular}

Keterangan: informasi harga produk per tablet diperoleh dari sebuah rumah sakit swasta di Surabaya, *durasi penggunaan selama 12 minggu

Keterbatasan informasi terkait perbandingan harga yang dipaparkan pada kajian naratif ini adalah hanya memaparkan data biaya langsung medis, khususnya komponen obat. Idealnya, analisis farmakoekonomi dengan membandingkan beberapa komponen biaya (cost) dibandingkan dengan luaran (outcomes) klinis atau humanistik (contoh: kualitas hidup) atau monetary (misal biaya untuk ROTD yang dapat dihindarkan) diperlukan untuk menunjukkan cost effectiveness penggunaan imidafenacin terhadap jenis antimiskarinik yang lain. Namun, sampai dengan tulisan ini dibuat, belum terdapat bukti penelitian terkait studi farmakoekonomi imidafenacin yang dilakukan di setting Indonesia. Dengan kata lain, kajian naratif ini dapat ditindaklanjuti dengan penelitian farmakoekonomi sebelum menggunakan imidafenacin pada lingkup yang lebih luas.

\section{DAFTAR PUSTAKA}

Arnold, J., McLeod, N., Thani-Gasalam, R., \& Rashid, P. (2012). Overactive bladder syndrome: management and treatment options. Australian Family Physician, 14(4), 211-217. https://doi.org/10.5114/ pm.2015.56403

Badan Pengawas Obat dan Makanan Republik Indonesia. (2015a). Mictonorm. Pusat Informasi Obat Nasional. http://pionas.pom.go.id/obatbaru/mictonorm

\section{SIMPULAN}

Imidafenacin merupakan obat baru yang dapat dipertimbangkan untuk digunakan pada pasien dengan overactive bladder (OAB). Secara umum, efektivitas imidafenacin tidak lebih superior dibandingkan dengan jenis antimuskarinik lain yang terdapat di Indonesia. Secara farmakodinamika, selektivitas imidafenacin terhadap reseptor M3 lebih baik dan hal tersebut berpengaruh terhadap risiko munculnya beberapa ROTD yang lebih kecil. Bila ditinjau dari sisi biaya, imidafenacin memiliki harga yang relatif lebih rendah dibandingkan dengan tolterodine, propiverine, dan solifenacin (10mg).

Badan Pengawas Obat dan Makanan Republik Indonesia. (2015b). Tolterodin tartrat. Pusat Informasi Obat Nasional. http:// pionas.pom.go.id/search/node/TOLTERO DINE

Badan Pengawas Obat dan Makanan Republik Indonesia. (2015c). Uritos tablet selaput $0,1 m g$. Pusat Informasi Obat Nasional. http://pionas.pom.go.id/obat-baru/uritostablet-salut-selaput-01-mg

Badan Pengawas Obat dan Makanan Republik 
Indonesia. (2015d). Vesicare tablet 5mg. Pusat Informasi Obat Nasional. http://pionas.pom.go.id/obat-baru/vesicaretablet-5mg

Badan Pengawas Obat dan Makanan RI. (2019). Cek Produk BPOM. Pusat Informasi Obat Nasional. https://cekbpom.pom.go.id/index. php/home/produk/j0a3m9hov94ebj4gnajrq 0aev7/all/row/10/page/1/order/4/DESC/sea $\mathrm{rch} / 5 /$ imidafenacin

Corcos, J., Przydacz, M., Campeau, L., Gray, G., Hickling, D., Honeine, C., Radomski, S. B., Stothers, L., \& Wagg, A. (2017). CUA guideline on adult overactive bladder. Canadian Urological Association Journal, 11(5), E142-E173. https://doi.org/10.5489 /cuaj. 4586

Eapen, R. S., \& Radomski, S. B. (2016). Review of the epidemiology of overactive bladder. Research and Reports in Urology, 8, 7176. https://doi.org/10.2147/RRU.S102441

Gormley, E. A., Lightner, D. J., Burgio, K. L., Chai, T. C., Clemens, J. Q., Culkin, D. J., Das, A. K., Foster, H. E., Scarpero, H. M., Tessier, C. D., \& Vasavada, S. P. (2012). Diagnosis and treatment of overactive bladder (non-neurogenic) in adults: AUA/SUFU guideline. Journal of Urology, 188(6 SUPPL.), 2455-2463. https://doi.org /10.1016/j.juro.2012.09.079

Huang, W., Zong, H., Zhou, X., Wang, T., \& Zhang, Y. (2015). Efficacy and safety of imidafenacin for overactive bladder in adult: a systematic review and metaanalysis. Int Urol Nephrol, 77. https://doi.org/10.1007/s12262-015-1264-1

Jayarajan, J., \& Radomski, S. B. (2013). Pharmacotherapy of overactive bladder in adults: A review of efficacy, tolerability, and quality of life. Research and Reports in Urology, 6(1), 1-16. https://doi.org/10.2147 /RRU.S40034

Kobayashi, F., Yageta, Y., Segawa, M., \& Matsuzawa, S. (2011). Effects of Imidafenacin (KRP-197/ONO-8025), a New Anti-cholinergic Agent, on Muscarinic Acetylcholine Receptors. Arzneimittelforsc hung, 57(02), 92-100. https://doi.org/10. 1055/s-0031-1296589

Maggiore, U. L. R., Scala, C., Venturini, P. L., \& Ferrero, S. (2013). Imidafenacin for the treatment of overactive bladder. Expert Opinion on Pharmacotherapy, 14(10), 1383-1397. https://doi.org/10.1517/ 14656566.2013.796930

Nazir, J., Kelleher, C., Aballéa, S., Maman, K., Hakimi, Z., Mankowski, C., \& Odeyemi, I. (2018). Comparative efficacy and tolerability of solifenacin $5 \mathrm{mg} /$ day versus other oral antimuscarinic agents in overactive bladder: A systematic literature review and network meta-analysis. Neurourology and Urodynamics, 37(3), 986-996.

https://doi.org/10.1002/nau.23413

Ono Pharmaceutical Co. (2010). Approval received for orally disintegrating tablet of imidafenacin (INN), a drug for overactive bladder. https://www.ono.co.jp/eng/news /pdf/sm_cn101111.pdf

Shah, D., \& Badlani, G. (2002). Treatment of overactive bladder and incontinence in the elderly. Reviews in Urology, 4 Suppl 4, S38-43. http://www.ncbi.nlm.nih.gov/ pubmed/16986020\%0Ahttp://www.pubme dcentral.nih.gov/articlerender.fcgi?artid=P MC1476020

Takeuchi, T., Zaitsu, M., \& Mikami, K. (2013). Experience with imidafenacin in the management of overactive bladder disorder. Therapeutic Advances in Urology, $5(1)$, 43-58. https://doi.org/10.1177/1756287212459549

Wolff, G. F., Kuchel, G. A., \& Smith, P. P. (2014). Overactive bladder in the vulnerable elderly. Research and Reports in Urology, 6, 131-138. https://doi.org/10.2147/RRU .S41843

Wu, J. P., Peng, L., Zeng, X., Li, H., Shen, H., \& Luo, D. Y. (2020). Is imidafenacin an alternative to current antimuscarinic drugs for patients with overactive bladder syndrome? International Urogynecology Journal. https://doi.org/10.1007/s00192020-04329-X

Yamada, S., Ito, Y., Nishijima, S., Kadekawa, K., \& Sugaya, K. (2018). Basic and clinical aspects of antimuscarinic agents used to treat overactive bladder. Pharmacology and Therapeutics, 189, 130-148. https://doi.org/ 10.1016/j.pharmthera.2018.04.010 